\title{
Development of Hunting Tourism in Vojvodina
}

\author{
Zoran A. Ristić', Vladimir Markovićc ${ }^{1 *}$, Milosava Dević \\ Received: June 2008 | Revised: April 2009 | Second Revised: July 2009 | Accepted: July 2009
}

\begin{abstract}
The first records on hunting in Vojvodina date from Roman and Byzantine Empires. Medieval hunting in Vojvodina was described by Nikola Zrinjski (1562), Edward Brown from England (1669) and Wilhelm Taube from Vienna (1777). According to those accounts, there were many marsh birds, and deer and does in Srem.

The first hunting law had been mentioned in 1504 and after that, Austrian hunting laws in 1729, 1743 and 1786. In 1883 the Hunting law was passed. At the end of 19th century there were hunting grounds managed by owners of large estates (Count Chotek in Futog, hunting grounds Futog-Irmovo, estate Schonborn-Pallavichini, Dunđerski family (Čib, Srbobran, Kulpin, Kamendin, Hajdučica), Count Andrija Čekonić in Žombolja and Nemačka Crnja, Count Harnacourt in Ečka, Count Karasconyi in Beodra (Novo Miloševo), estate Lederer in Oak and estate of Duke I. Odescalschi in llok etc.
\end{abstract}

Hunting tourists were more interested in a small game hunting. So-called "golden" times of hunting tourism had begun in 1966, when more than 1000 foreign tourist hunters came to Vojvodina (in season 1966/67 1665 hunting tourists), and lasted to 1990/91 hunting season when 7053 hunting tourists were registered.

After this period, hunting tourism in Vojvodina collapsed due to well-known reasons (civil war, immediate war danger, sanctions etc.). After situation settled down at the beginning of 21st century, hunting tourism in these areas is slowly recovering.

Key words: hunting, hunting tourism, hunting grounds, large game, small game

\section{Introduction}

The first records on hunting date from period of Roman and Byzantine Empires. In those times, rulers organised hunting around Danube and Sava rivers and in Fruška gora.

Vojvodina was characterised by vast areas of steppe and wastelands, ponds and forests. Those were favourable habitats for numerous and diverse game species.

Medieval hunting in Vojvodina area was more important, described by Nikola Zrinjski (1562), English author Edward Brown who travelled Srem in 1669 and by Vienna court official Wilhelm Taube, who travelled Vojvodina in 1776 and 1777. According to their accounts, there were many marsh birds, as well as deer and does in Srem (Ristić, 2007b).

During medieval times, the right to hunt belonged solely to nobility, high officials and officers. The custom was that estate owner will organise hunting for his guests, lasting even several days.

Freemen, serfs and common soldiers were prohibited from hunting. This was stated in the Hunting law from 1504.

The game was hunted in different ways: by snares, nets, dogs, falcons and guns. According to Taube, in Vojvodina between $17^{\text {th }}$ and $18^{\text {th }}$ century hunting with trained falcons was quite common, especially for small game birds (Ristić, 2007a).

After expelling Ottoman Empire, Austrian government passed a number of laws for newly liberated areas. Hunting laws were passed in 1729, 1743 and 1786; hunting grounds were divided to state, private, monastery and bishopric ones. Laws issued that every hunting ground must have area devoted to breeding game, and that in this area hunting is prohibited.

According to the Hunting Law from 1883 , owners of estate exceeding 200 acres had exclusive right to hunt in this

\footnotetext{
1 Department of Geography, Tourism and Hotel Management, Faculty of Science, University of Novi Sad, Trg Dositeja Obradovića 3, 21000 Novi Sad, Serbia

* Corresponding author: Vladimir Marković, e-mail: Vladimir.Markovic@dgt.uns.ac.rs
} 
territory. Lots under 200 acres were united by municipalities and rented out to 6 and 10 years.

In this period in Vojvodina, hunting societies were formed in following order, according to archive funds (Petrović S., 1992. and March 25 th 2003): 1. Petrovaradin - 1873; 2. Bela Crkva - 1874; 3. Pančevo - 1882; 4. Novi Sad - 1883; 5. Senta - 1884; 6. Kikinda I - 1885; 7. Novi Bečej - 1885; 8. Vršac - 1894; 9. Subotica, "Nimrod" - 1897; 10. Subotica, "Diana" 1897; 11. Titel - 1898; 12. Kikinda II - 1898; 13. Kanjiža - 1900; 14. Stari Bečej - 1904; 15. Bačka Palanka - 1905; 16. Padej 1907; 17. Bačka Topola, county - 1907 (Bajša, Pačir, Moravica, Čantavir); 18. Opovo - 1908; 19. Jabuka - 1908; 20. Alibunar 1908; 21. Zrenjanin - 1908; 22. Glogonj - 1908; 23. Srbobran 1910; 24. Crvenka - 1910; 25. Čurug - 1912; 26. Bačko Gradište - 1913; 27. Novi Sad (Čenej) - 1913; 28. Futog - 1913; 29. Riđica 1914; 30. Žabalj - 1914; 31. Perlez - 1914; 32. Kikinda, "Diana" 1914; 33. Apatin - 1914 (Marinović, 1930).

\section{Development of hunting tourism from 1936 to 1955 year}

Beginnings of hunting tourism are dating much before official founding of Hunting association and Hunting Co-operative, which is known due to written materials in hunting magazines before Second World War. A part of these materials is published in a monograph of Hunters Association of Vojvodina, in 1992, covering development of hunting in Vojvodina from 1922 to 1992. Due to these written words, we are able to talk about beginning in development of hunting tourism in Vojvodina (Novkov, Ristić, 1992).

"Lovački glasnik", No. 3-5 from 1936, under headline "Foreigners and our game", hunting tourism if mentioned for the first time. This article says that: "Some foreign hunters tourists, especially Englishmen, are looking for the possibility to hunt certain game species with appropriate reimbursement ".

In order to get a glimpse of hunting worldwide, Hunters Association secretary Joca Divild organised a 370-members delegation from Vojvodina to travel by the special hunter's train to exhibition in Berlin. There they met important people in hunting, initiated contacts with hunters from other countries, and therefore promoted hunting in Vojvodina. In next year, first guests from Germany arrived (30 to 40 hunters) taking part in hunting the small game in Vojvodina.

In this period, Vojvodina had excellent game funds, and one of most important criteria in its evaluation is certainly a catch number in the same period. For instance, in 1937 total catch in Vojvodina was: 157805 hares, 5931 pheasants, 35750 grey partridges, 11986 quails, 5563 wild pigeons, 20402 wild ducks, 3379 moorhens, 7062 wild geese - or, in total, 252805 of protected game species. In following year 1938 , the catch was: 190778 hares, 7703 pheasants, 44453 grey partridges, 11411 quails, 5756 wild pigeons and doves, 29670 wild ducks, 5382 wild geese, 5269 moorhens - or, in total, 305282 of protected game species.

After the Second World War, and especially at the beginning of 50's, it was accepted that our country, and especially Vojvodina, has potential for development of international hunting tourism, if a game resources are being rationally breeding and protected.
Beginnings of hunting tourism development were connected to a large game. The bylaws and price lists were prepared. The first offers of our trophy deer had results and for eign hunters were unexpectedly interested. This offer was published in Hunters' magazine "Lovac" No. 5 from 1952 (This was the magazine of Association of hunters' societies of Republic of Serbia). At the page 110, author N.N. publish es article "International hunting tourism in FNRJ: Foreign hunters caught the first deer".

\section{Development of hunting tourism from 1955 to 1980 year}

At the beginning of 1950's, promotion and development of hunting tourism in Vojvodina were taken over by Hunt ing Association of Vojvodina. Hunting tourism in Vojvodina was discussed even before foundation of Hunting Cooperative of Vojvodina, on June $29^{\text {th }} 1955$. In the same year the Co-operative began to promote hunting tourism, and to sell game in behalf of interested organisations in possession of large game hunting grounds.

Hunting Association of Vojvodina published a price list for foreign hunting tourism:

- to enter the hunting grounds for pheasant game: $8,5 \mathrm{US} \$$ (for hare 6,5US\$)

- hunting fee for a pheasant $1 \mathrm{US} \$$, same as for hare, while fee for a wild duck or goose is $0,25 \mathrm{US} \$$

- hunting of up to 5 hares, and up to 3 pheasants is allowed; for marsh birds hunting is unlimited

- every game specimen caught over the limit is to be paid extra, for instance hare $3,5 \mathrm{US} \$$, pheasant ${ }_{5} \mathrm{US} \$$ and duck $0,35 \mathrm{US} \$$.

Full board for foreign hunting tourists costs 10US \$ per day.

On the basis of 1963 price list, game was to be paid for: partridge, hare, pheasant 2 dollar each; wild duck one dollar each, while meat was paid according to trading price list.

For the next year hunting fee was 4 dollars for hare and pheasant, 3 dollars for partridge, 2 dollars for wild duck, and 0.8 dollars for collared dove and quail.

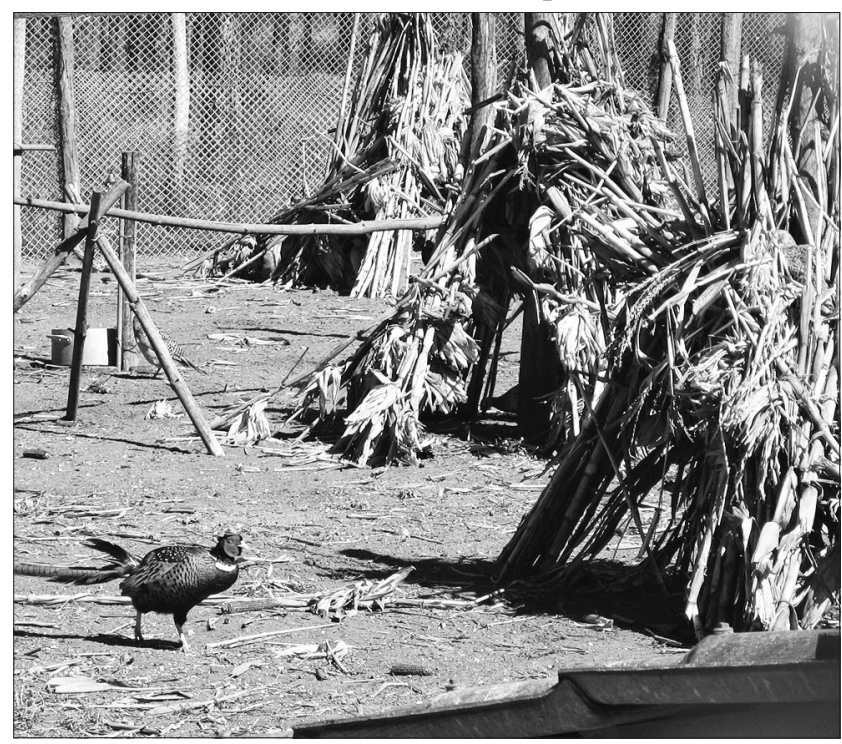

Figure 1 Pheasant is most interesting small game in Vojvodina Source: Ristic, 2002 


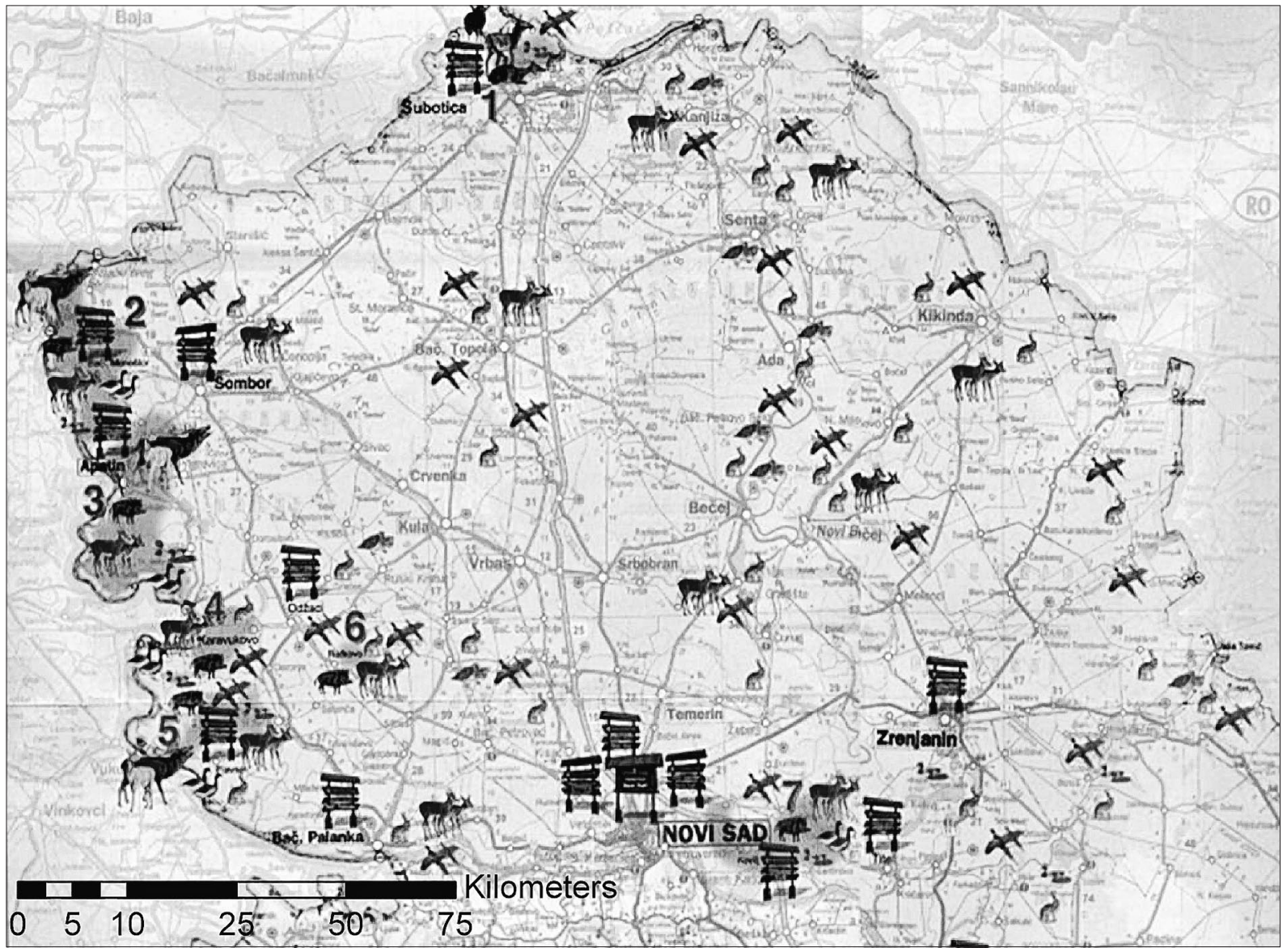

Figure 2 Hunting funds in Vojvodina

Source: www.vojvodinasume.co.rs

In 1965 prices are given in Italian lire, as well as taxes and organisation. Catch fees for hare, partridge and pheasant are all the same $4,5 \mathrm{US} \$$. For comparison, in 1970 fee was for hare $8,5 \mathrm{US} \$$, for pheasant ${ }_{5} \mathrm{US} \$$, for partridge ${ }_{5} \mathrm{US} \$$, wild duck $3,5 \mathrm{US} \$$, collared dove $0,5 \mathrm{US} \$$, quail $1 \mathrm{US} \$$ and doe and fawn $42 \mathrm{US} \$$.

In "Lovačke novine" from September $9^{\text {th }} 1963$, in article "Hunting tourism in 1963", it is said that Hunting Co-operative in hunting tourism planned to collect 50.00oUS\$. During the hunting season, hunting tourism provided about 42.00oUS\$. In the same year, a leaflet was printed in Italian, propagating conditions for hunting in Vojvodina.

In "Lovačke novine" from September $1^{\text {st }} 1964$, article said: "This year income of Hunting Co-operative of Vojvodina is about 500000 dollars". From hunting tourism in 1963 about 450000 dollars is realised, while in 1964 double income is expected, since arrival of about 2000 hunting tourists in hunting grounds of Vojvodina is contracted.

In "Lovačke novine" From August $1^{\text {st }}$ 1966, article "To affirm Vojvodina as hunting-tourism region", discusses problems in hunting tourism, development possibilities and intense promotion of Vojvodina hunting. The same article said: "Hunting tourism in Vojvodina exists for several years and there was no great progress; main reasons of stagnation are poor promotion, non-synchronised actions, poor preparations for arrival of tourists and other factors, but most certainly not the lack of game. This harsh judgement is less expressed in real conditions, but is meant for unused possibilities for more rapid development of hunting tourism, game export and hunting in general".
"Lovačke novine" No. 109 from 1966, writes that Co-operative established contacts with hunters, tourist and other magazines and certain tourist agencies in Italy. During May and June press conferences were held in Turin, Milan, Florence and Rome for about 30 magazines, not only hunting and tourist ones but others as well, and for representatives of radio and television, successfully promoting hunting tourism offer in Vojvodina. A specialised agency SIT (International tourism organisation) in Rome was hired. This organisation alone invested more than 20.00oUS $\$$ in promoting our hunting tourism, and our Hunting Co-operative established closer co-operation with its partners.

In "Lovačke novine" from December $15^{\text {th }} 1966$, article "Hunting tourism in Vojvodina" says that as a guests of Hunting Co-operative, representatives from large Italian travel agency SIT have been in Vojvodina hunting grounds during summer. Apart of this Italian organisation, editors of Italian magazines "Unita" and "Paese sera" were also visiting dozen hunting organisations in Vojvodina, telling their readers in detail about it. Representatives of hunting associations from Bologna and Modena were also visiting. Within promotion of hunting tourism, Hunting Co-operative of Vojvodina organised on December 11th 1966, in hunting grounds "Ristovača" hunting for foreign reporters accredited in Yugoslavia (Jović, 1968).

Province of Vojvodina was the pioneer in this activity, generating development. This is corroborated by facts published in hunting magazines, namely in Belgrade "Lovac" from 1966/67. Author B. Tomašević in article "Hunting in Serbia” provides facts: “...interest of foreign hunters in in- 
creasing daily, so number of their visits and hunting rises every year. At the same time, foreign currency income also rises, and in last two years income amounts to 166.898 USA dollars, from which more than $90 \%$ in Vojvodina".

In 1967700.000 specimens of various game were offered to foreign hunting tourists. From this 9000 were hares, and other were game birds. Hunting grounds in Vojvodina had 52 hunting homes in 1967, in 5 categories. Best and most comfortable were castles, with 173 beds, second category were mansions with 97 beds, hunting homes with 83 beds, hunting houses with 86 beds and hunting huts with 20 beds.

During preparations for hunting-tourism season, Hunting Co-operative organised seminaries for hunters guides, translators, cooks and others who will take part in organisation and reception of hunting tourists. The Hunting Co-operative of Vojvodina organised stay of 382 hunting tourists (from total of 458) who have been hunting in 15 hunting associations and bagged as follows: 3125 hares, 3726 pheasants, 1218 partridges, about 3000 wild ducks, 115 does, 6 wild boars and about 5000 other small game. For foreign hunting tourists from Italy about 100000 leaflets were printed.

First hunters from Italy in hunting grounds in Vojvodina were brought by Mr. Ivo Duranti, official of hunting organisation in Italian region Arezzo, reporter for a number of Italian magazines and hunting magazines. His articles in Italian newspapers had immense influence to animate and bring Italian hunters in Vojvodina hunting grounds.

It is interesting that the first foreign hunters came to Vojvodina hunting rounds in order to hunt large game, but preferences changed quickly and interest for large game decreased while interest for small game was rising. Italian hunting tourists at first sought pheasants, then partridges, and in 1968 a hunting-tourist "boom" occurred in dove hunting. In fees for doves only, more than 20.00oUS\$.were collected from Italian hunters in 1970 (and in those times this was more than significant amount).
In "Lovačke novine" from June $15^{\text {th }} 1970$, in article "From International hunting exhibition in Turin", it is said that the International exhibition of hunting and fishing was held in Turin between March $5^{\text {th }}$ and $15^{\text {th }} 1970$, and that Hunting Co-operative from Novi Sad also was present. The Co-operative had its boot, arranged with tasteful care, where large number of hunters have been coming to contract hunting and sign long-term arrangements with large number of clients from numerous Italian regions.

In "Lovačke novine" from December $15^{\text {th }} 1970$, article “Ten years of hunting tourism in Vojvodina", describes the end of tenth hunting-tourism season in Vojvodina. In ten years of hunting tourism in Vojvodina total of 50000 hunting days was realised through Hunting Co-operative of Vojvodina, with 1.050.00oUS\$. income from small game sale. Every year (between 1961 and 1970) in average between 500 and 3000 hunters-tourists had come, and income of 210.000 US \$ was realised. For example, in 1960/61 season in Vojvodina only 48 hunter-tourists came through Hunting Co-operative of Vojvodina, and in 1970/71 season 3,560 hunters-tourists came (through Hunting Co-operative of Vojvodina) and in Vojvodina, in total, 3,606 hunters-tourists in the season. It is evident that in 10 years number of hunting tourists in Vojvodina increased more than 75 times.

In hunting tourism in Vojvodina, year 1974 was by far most dynamic, unique in many ways. In last week of October the finale of one of most interesting hunting-media manifestation in France was held, devoted to hunting abroad, named "Op eration faisans" (operation pheasant); and the epilogue was in Novi Sad. In organisation of "Radio Europe 1", together with "Pernod", "Gevelot", and the host, "Quattro cervi" Agency as part of Hunting Co-operative of Vojvodina, almost 300 hunters from France stayed in Vojvodina hunting grounds, who came by JAT aeroplanes. Within "Operation pheasant", hunting grounds for French hnters were offered also in Canada, Ireland, Czechoslovakia and Romania. But Vojvodina had

Table 1 Number and catch in hunting tourism in Vojvodina in period from 1964/65 to 1969/70 (Ristić, 2005)

\begin{tabular}{|c|c|c|c|c|c|c|c|c|}
\hline \multirow{2}{*}{ Year } & \multicolumn{2}{|c|}{ Doe } & \multicolumn{2}{|c|}{ Partridge } & \multicolumn{2}{|c|}{ Hare } & \multicolumn{2}{|c|}{ Pheasant } \\
\hline & Number & Catch & Number & Catch & Number & Catch & Number & Catch \\
\hline $1964 / 65$ & 20595 & 58 & 242859 & 1346 & 307674 & 2863 & 127412 & 4634 \\
\hline $1965 / 66$ & 22657 & 99 & 233074 & 1161 & 300048 & 1863 & 140096 & 2806 \\
\hline $1966 / 67$ & 23253 & 180 & 231411 & 805 & 294531 & 2341 & 182814 & 4756 \\
\hline $1967 / 68$ & 23256 & 231 & 226761 & 1169 & 272835 & 3688 & 174496 & 6702 \\
\hline $1968 / 69$ & 22250 & 316 & 190922 & 2469 & 221600 & 5003 & 149660 & 10023 \\
\hline $1969 / 70$ & 23779 & 344 & 223699 & 3822 & 204926 & 5258 & 176145 & 11879 \\
\hline \multirow{2}{*}{ Year } & \multicolumn{4}{|c|}{ Catch } & \multirow{2}{*}{\multicolumn{4}{|c|}{ Other game birds }} \\
\hline & Fallow deer & Deer & Mouflon & Wild boar & & & & \\
\hline $1964 / 65$ & 5 & 44 & - & 23 & \multicolumn{4}{|c|}{231} \\
\hline $1965 / 66$ & 1 & 72 & - & 26 & \multicolumn{4}{|c|}{1878} \\
\hline $1966 / 67$ & 7 & 112 & 3 & 32 & \multicolumn{4}{|c|}{3736} \\
\hline $1967 / 68$ & 12 & 125 & 3 & 33 & \multicolumn{4}{|c|}{2085} \\
\hline $1968 / 69$ & 3 & 127 & - & 60 & \multicolumn{4}{|c|}{13028} \\
\hline $1969 / 70$ & 12 & 164 & 1 & 125 & \multicolumn{4}{|c|}{11120} \\
\hline
\end{tabular}


Table 2 Number of foreign hunting tourists in Vojvodina per year, from 1961/62 to 1970/71 (Ristić, 2005)

\begin{tabular}{|c|c|c|c|c|c|c|}
\hline Year & $\begin{array}{l}\text { Hunting Cooperative } \\
\text { of Vojvodina }\end{array}$ & Income (US\$) & "Jelen" Beograd & Income (US\$) & Total hunters & $\begin{array}{l}\text { Total income } \\
\text { (US\$) }\end{array}$ \\
\hline $1961 / 62$ & 48 & 11250 & - & - & 48 & 11250 \\
\hline $1962 / 63$ & 118 & 15850 & - & - & 118 & 15850 \\
\hline 1963/64 & 765 & 60558 & - & - & 765 & 60558 \\
\hline $1964 / 65$ & 603 & 51000 & 10 & 20200 & 613 & 71200 \\
\hline $1965 / 66$ & 534 & 42750 & 15 & 12924 & 549 & 55674 \\
\hline 1966/67 & 739 & 70000 & 56 & 22471 & 795 & 92471 \\
\hline 1967/68 & 1595 & 140000 & 70 & 101902 & 1665 & 241902 \\
\hline $1968 / 69$ & 1900 & 170000 & 51 & 90632 & 1951 & 260632 \\
\hline $1969 / 70$ & 3020 & 310000 & 81 & 127093 & 3101 & 437093 \\
\hline 1970/71 & 3560 & 325000 & 46 & 35406 & 3606 & 360406 \\
\hline
\end{tabular}

Source: Bugarski, D.1972

distinctive advantage. Between October $21^{\text {st }}$ and $30^{\text {th }} 1974$ Vojvodina hunting grounds were a spectacle to be remembered. "Operation pheasant" was evaluated as a great success, world press wrote about it, and consequently "Quattro cervi" Agency of Hunting Co-operative of Vojvodina, was listed as one of most capable and most professional agencies of the kind in the world. After "Operation pheasant", Vojvodina hunting grounds near Ada, Mol, Padej, Senta, Ruski Krstur and "Ristovača" near Bač, became world-known (Todorović, 1976).

\section{Development of hunting tourism from 1981 to 1990 year}

In 1980 , prices of game were: hare $25 \mathrm{US} \$$, pheasant, partridge and wild duck $7 \mathrm{US} \$$ each, collared dove and quail $2 \mathrm{US} \$$ each, doe and fawn $70 \mathrm{US} \$$.

In 1990, hare price was $50 \mathrm{US} \$$, pheasant $14 \mathrm{US} \$$, partridge $17,5 \mathrm{US} \$$, wild duck $14 \mathrm{US} \$$, collared dove $3 \mathrm{US} \$$, quail ${ }_{4} \mathrm{US} \$$, doe and fawn $140 \mathrm{US} \$$.

Game prices in foreign hunting tourism were listed in Italian lire until 1995, and between 1995 and 2000 in German marks. In 2000 prices of game for foreign hunting tourism were hare $65 \mathrm{DM}(45 \mathrm{US} \$)$, pheasant $22 \mathrm{DM}(15 \mathrm{US} \$)$, partridge $30 \mathrm{DM}(21 \mathrm{US} \$)$, wild duck $22 \mathrm{DM}(15 \mathrm{US} \$)$, collared dove and quail $5 \mathrm{DM}(3,5 \mathrm{US} \$)$, doe and fawn $250 \mathrm{DM}(175 \mathrm{US} \$)$ (Ristić, 1995). From 2002 game prices in hunting tourism are given in Euro. Prices are still the same: hare 33 Euro; pheasant and wild duck 11 Euro, partridge 25 Euro wild goose 20 Euro, teal duck 8 Euro; collared dove and quail 2.5 Euro, turtledove 2 Euro; doe and fawn 125 Euro. Since 2006 since our veterinary certificates are not valid at customs any more, prices are divided into a fee with and without taking the meat. Therefore: hare 33 Euro, or without meat (hunting fee) 25 Euro; pheasant 11 (8) Euro; partridge 25 (22) Euro; collared dove and quail 2.5 (2) Euro (Graph 1.).

Intensive hunting-tourist activities in Vojvodina lasted until 1990, and between three and five thousand foreign hunters came to hunt for collared doves, turtledoves, partridges and wild ducks, and in fall one to two thousand hunters hunting hare, pheasant, quail, wild ducks, wild geese and doe. All this caused huge introduction of pheasant chicks and so in fall hunting pheasants was emphasised, in order to protect hare and quail as autochthonous species.
Organisers insisted that for every hare bagged at least 5 to 10 pheasants must follow.

Period between 1970 and 1990 is certainly most prosperous time of hunting tourism in Vojvodina. In this period, by "Quattro cervi" agency, three to eight thousand hunters came to Vojvodina. In these years, foreign hunters used between 10 and even 22 thousand hunting days in our hunting grounds. In every year, by mediation of "Lovoturs" (or Hunting Co-operative of Vojvodina) they had caught in average between three and eight thousand hares, 20 to 35 thousand pheasants, one to eight thousand partridges, one o six thousand wild ducks, 100 to 800 does and fawn, couple dozens to 400 roebucks, up to 45 thousand partridges and several thousands of other small game. Results of catch of pheasants and wild ducks were followed by improving results in introduction of these game species into hunting grounds, using so-called "artificial breeding".

"Lovačke novine" from April 1st 1988, in article "Six million dollars income" write: "When there is no accidents like Chernobyl, and when enough attention is being paid

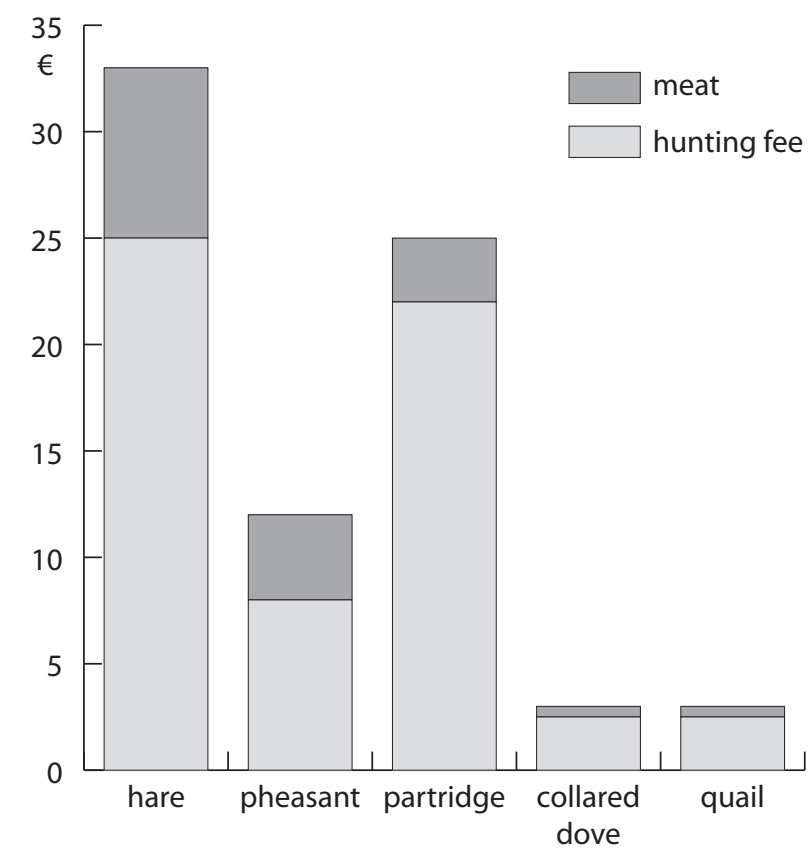

Graph 1. Structure of game prices from 2006 


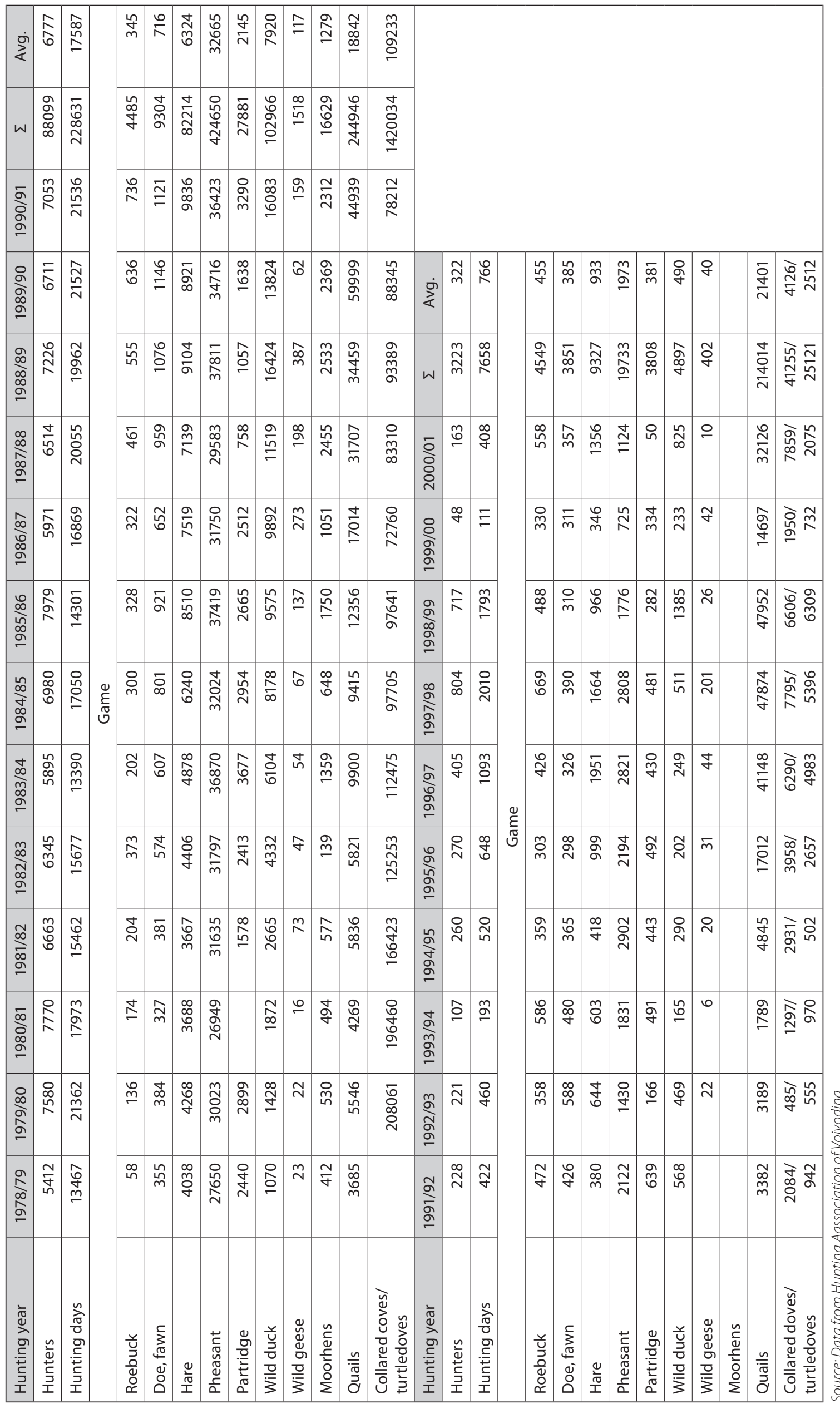


to promotion abroad, with existing conditions in hunting organisations, there are chances to improve considerably foreign-currency income from foreign tourists coming to hunt in Vojvodina hunting grounds. This was the case in $1987 / 88$ hunting-tourist season, when from 6500 hunters total income was six million dollars. These tourists had over 20000 boarding days, and have caught 460 roebucks, about 1000 does, 30000 pheasants, 7000 hares, twice more moorhens than in previous season, about 83000 turtledoves and collared doves, from which about $80 \%$ was autochthonous, 32000 quails and 11500 wild ducks. Income is twice as high as in 1986/87 season, and merits go to "Lovoturs" that realised about 4.400 .000 US\$".

The best results in hunting tourism had the hunters in hunting societies Bačka Topola, Senta, Novi Kneževac, Novi Bečej and Horgoš, which certainly contributed to enhanced development of hunting in their communities. It is interesting that there was much more interest for pheasant hunting than it was possible to fulfil, and about $20 \%$ demands was not satisfied. There were no enough hares too, due to storms with hail in Vojvodina that season. But the number of bagged roebucks, turtledoves and collared doves, partridges and wild ducks was increased.

\section{Development of hunting tourism from 1991 to nowadays}

Due to crisis (civil war, immediate war danger, sanctions imposed to our country, etc.) after 1990, interest of foreign hunting tourists for hunting grounds of Vojvodina rapidly decreased, even in spite of several decades of tradition. This is understandable, since the tourism is most sensitive branch, especially hunting one, which includes armed persons, in this case foreigners, moving through hunting grounds and exporting meat over the state boundaries, and those are necessary elements in this branch of economy. Therefore hunting tourism is a specific branch of tourism, demanding different organisation and regime. Many intermediary agents tried to use this situation, doing business outside positive laws and other regulations, so in Vojvodina hunting grounds a havoc ensued (in a certain period) damaging game and hunting grounds ("Balkan birds" scandal) (Ristić, 2004). In order to avoid havoc in following period, it is necessary to regulate these matters by law, to pass norms and regulations, since this is the only way to protect all game species (which is only partly renewable resource) with much more investments in hunting grounds and game in order to provide development of this branch of economy in Vojvodina.

After sanctions were imposed to our country, hunting tourism decreased drastically. In spite of circumstances, "Lovoturs" with great efforts still maintained its contacts and co-operation with foreign hunting tourists, slowly bringing them back to Vojvodina. Price lists and programmes were sent to more than thousand addresses every year, and several favourable articles were published abroad. "Lovoturs" also invited foreign reporters for several times, enabling them to see for themselves that hunting might continue without obstacles (Ristić, 2005). Nevertheless, results were not satisfying. There are several reasons, one of

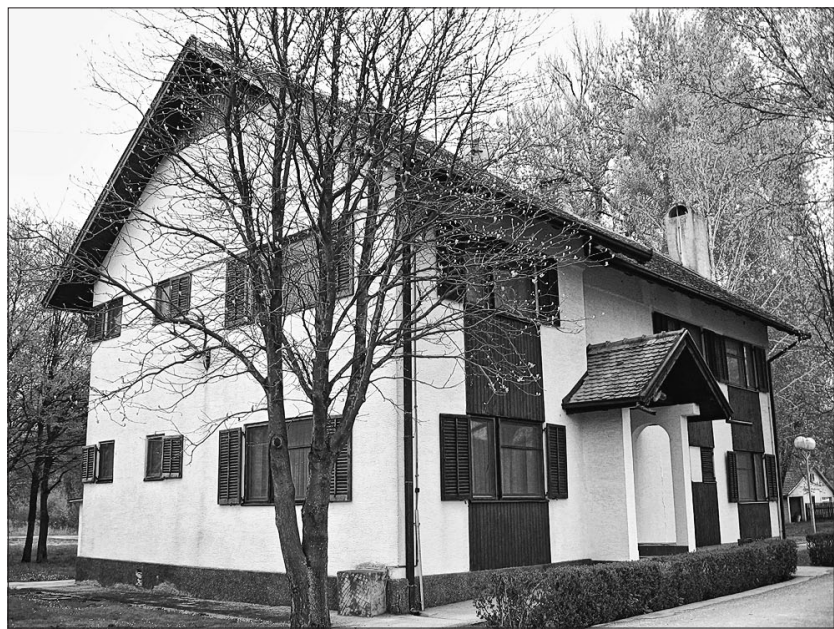

Figure 3 Hunting house "Mesarske livade" Source: Markovic, 2006

which is unfair competition by present hunting-tourist organisation, some of which are not respecting laws and regulations by Hunters Association of Serbia and by state Government.

Nevertheless, all efforts are gradually showing results, so the number of foreign hunting tourists is slowly increasing every year, but this is still far away from results possible in foreign hunting tourism, having in mind success up to 1990.

\section{Conclusions}

"Lovoturs" business unit, hunting-tourist agency "Quattro cervi" (Four deer), successfully operating more than 20 years, is well-known throughout the world. It successfully promoted hunting tourism in Vojvodina, and it achieved high respect abroad, mostly in Italy. For the last 30 years, it had important currency income, not only for "Lovoturs" and hunting organisations, but also for a society as a whole. Most of income was invested in breeding game, promotion, import of hunting equipment and accessories, and in science projects in hunting, in order to preserve existing game funds and to increase them when possible.

In Vojvodina, several agencies were involved in hunting tourism until 1987. The first one is certainly Hunting Cooperative of Vojvodina (from 1978 transformed into "Lovoturs"), then "Ečka" from Ečka, oriented to hunting water birds (mostly wild ducks and wild geese), "Jelen" from Belgrade, oriented to hunting trophy roebucks in Vojvodina, and from 1987 "Vojvodinaturs", which operated only for several years.

Present situation is quite different. According to available data, more than 20 intermediaries are involved in hunting tourism in Vojvodina, mostly organising small game hunting in summer season. Such large number of intermediaries in hunting tourism is derived from former workers in this business and from guides from "Lovoturs" - former Hunting Co-operative of Vojvodina. There are cases of gross sale of game, and giving hunting grounds in sublease, which is prohibited by law. To bring order in this area, it is necessary to involve inspection officers in order to prevent illegal actions, and hunting organisations must obey the present Hunting 
Table 4 Income from hunting tourism in Vojvodina

\begin{tabular}{|l|r|}
\hline Funds & \multicolumn{1}{|c|}{ US\$ } \\
\hline Hunt organization in Vojvodina & $14,171.912$ \\
\hline Boarding houses in Vojvodina & $38,986,824$ \\
\hline Bagging taxes in Vojvodina & $60,965,264$ \\
\hline Total & $1,354,784$ \\
\hline Average income from 1964 to 2008 &
\end{tabular}

Law and other bylaws and regulations regarding this matter, as well as current price-list of Hunting Association of Serbia.

Aside from the bagging taxes, each hunter was also charged with $15,5 \mathrm{US} \$$ per hunting day.

From 1964 to 2008 the number of visiting hunter - tourists was 178.650 or the year average of 3.970 hunters. This was the total of 462.704 hunting days, which means that the hunting organization charged 7.171.912US\$.

For lodging purposes, hotels or hunting lodges (average price of accomodations was around $32 \mathrm{US} \$$, for half board) the hunting organization was paid $14.806 .528 \mathrm{US} \$$.

Hunting in Vojvodina area from 1964. to 2008. made a total of 60.965.264US\$ (charged for hunting organisation, boarding and bagging taxes) (table 4 ).

In the first stage of that period of hunting tourism (1964 - 1980) funds made by charging for bagged game were 9.616.508US\$, or $24,67 \%$ of the total sum ( $38.986 .824 \mathrm{US} \$$ ), and, in the second, more intensive stage $(1981-1990)$ funds made were $17.139 .201 \mathrm{US} \$$ or $43,96 \%$, the third stage (from 1991 to 2008 ) funds made were $12.230 .115 \mathrm{US} \$$ or $31,37 \%$.

Hunters - tourists came from various countries, the number of hunters from Italia: 151.853; from Spain : 12.506; from Germany: 5.360; from Austria: 3.573 and the rest (hunters from Greece, Belgium, France and others) 5.358 hunters.

In a situation in which our country is, due to changes regarding countries of the main tourist market, decreased

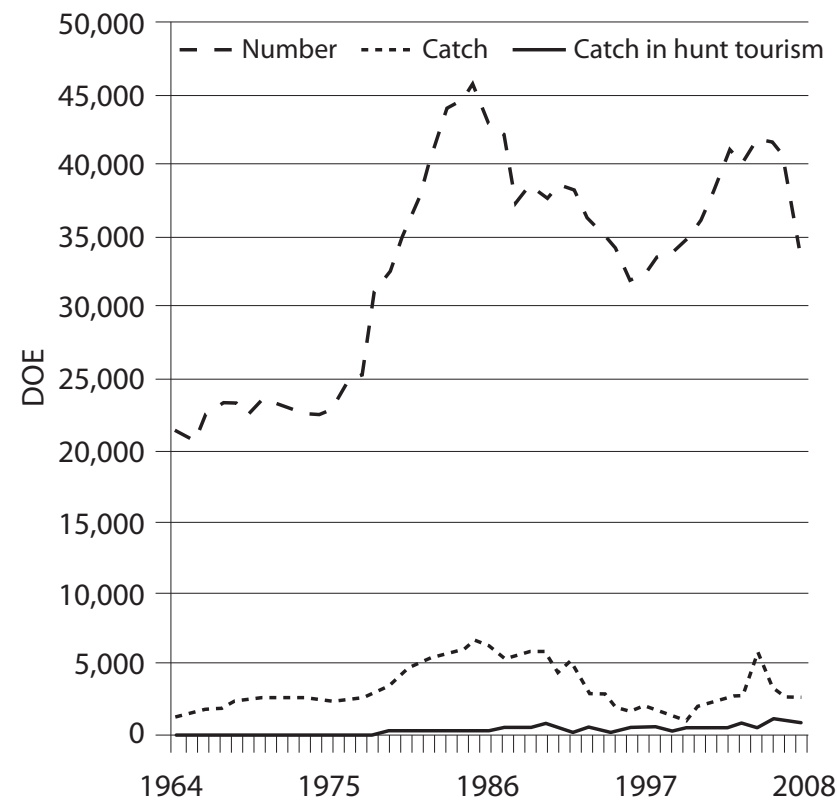

Graph 2 Doe in Vojvodina for period from 1964 to 2008 Source: Data from Hunting Aassociation of Vojvodina number of all game species, especially game birds (mainly pheasant and quail), which were taking main place in our hunting offers, it is very hard to make long-term plans for development of hunting tourism as a most propulsive way to "cash-in" the game.

Long-term measures may not count on normalisation of situation (political, social, economical etc.) in our nor in other countries. Vojvodina can not quickly reach results and level of hunting tourism from the beginning of eighties. Some relationships were made which must be counted on for the next period. The geopolitical position has been changed (we are not bordering with any of countries from potential market, as was the case before breakdown of Yugoslavia), new restrictive regulations of European Union are imposed regarding veterinary and health protection and visa regime. All this caused clients to switch to other markets for hunting tourism (Hungary, Czech Republic, Slovakia, Romania, Bulgaria, etc.), and number of hunters in countries of main tourist market has been decreasing (for instance, in Italy number of hunters decreased to onethird in last decade, from two million to about 650000).

Counting to gradual recovery of this industry, hunting organisations must be oriented to offer services that are most sought for in a hunting-tourist market, and that are easy to fulfil, mostly regarding restrictive regulations of European Union. This is mostly trophy hunting of roebucks and other large game, game bird hunting during the summer season (turtledove, partridge, wild duck, wild pigeon, etc.), and gradually, when a situation gets more normal, to increase number of breeding species and offer other species of small game, mostly pheasants.

In order to carry out the strategic decision, it is necessary to bring order in tourist agencies, to neutralise every kind of "black market" and private clearing, and to eradicate corruption. Important step in removing negative effects is the new Serbian Law on Hunting, as well as articles

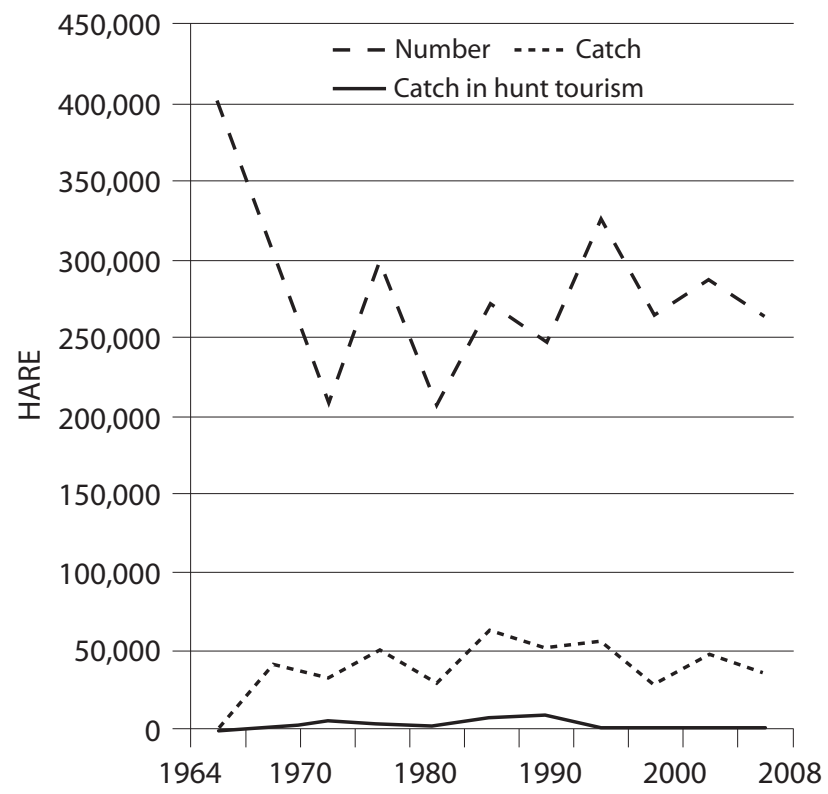

Graph 3 Hare in Vojvodina for the period from 1964 to 2008 Source: Data from Hunting Aassociation of Vojvodina 


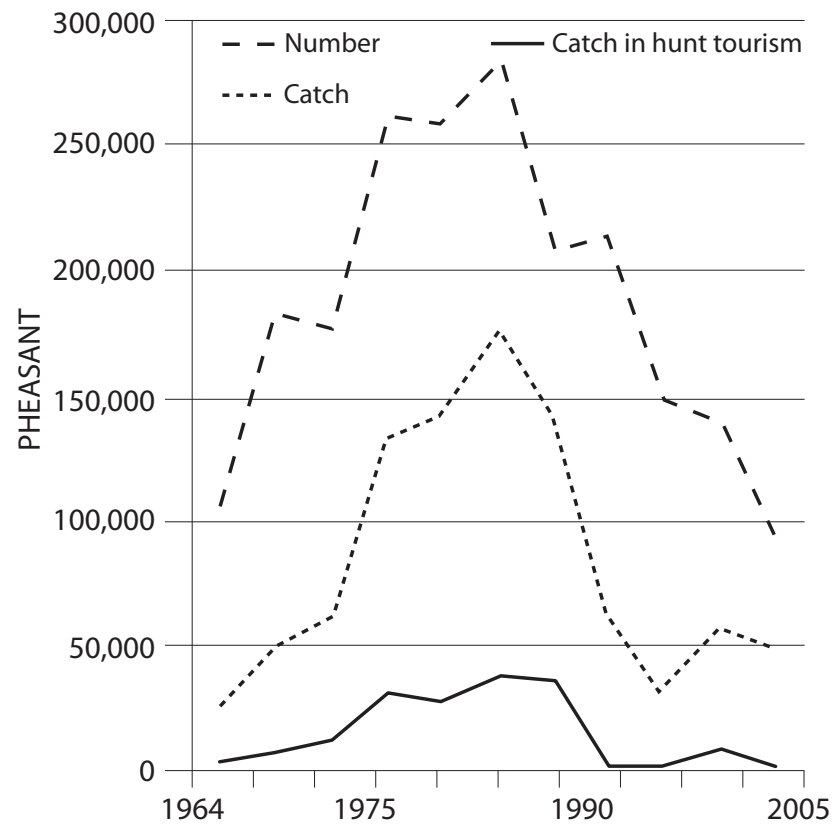

Graph 4 Pheasant in Vojvodina for period from 1964 to 2008 Source: Data from Hunting Aassociation of Vojvodina

and conditions of the Contract between Hunting Association of Serbia (as the primary user of most hunting grounds in Serbia) and the hunting societies, which got the hunting grounds from the Association, followed by the mandatory registration of the contract on hunting tourism in the Hunting Association of Serbia. These measures are meant to impose order and eradicate havoc, and not to strangle intermediary role of any subject who wishes to adhere to laws and regulations regarding this matter.

As the basis for further development of hunting tourism, efforts to increase the game numbers are crucial. Most of the quantities of various game are less then in the "golden years" of hunting tourism in Vojvodina (Graph 2-4). To increase the number of foreign hunters, and incomes from hunting tourism, it is necessary to at least reach the number of game from the eighties.

On the other hand, there must be more intensive efforts in eradicating numerous obstacles for this activities, on our side (visas, gun fees, restricted number of ammunition), in order to avoid any damages for society and a state. Some measures were revoked already, after initiatives from hunting association (lowered gun fees, increased number of ammunition).
When all assumptions are met concerning our hunting organisations and our country in general, Vojvodina might count on 2 to 2.5 thousand foreign hunting tourists every year, with effective currency income between 2.5 and 3 million Euro, which could be enough for serious investments in artificial breeding of game. Investments would be possible in pheasants, in new production objects, mostly for grey partridges, in improvement of lodging conditions for foreign hunting tourists, as well as in hunting grounds. Financial help from community will be necessary at least in first couple years, until a balance is established between resources needed for production, breeding and protection of game and the resources available from foreign hunting tourism.

As for the domestic hunting - tourism market, it will develop with the improvement of the country's economic status. The main focus should be on the game which has been raised artificially, like the pheasant, which the hunters have shown interest in.

\section{References}

Jovic, D. 1968. Problems of modulating foresting and hunt harvesting. Jelen 7,7-12.(in Serbian)

Marinovic, M. 1930. Economic importance of hunt in Yugoslavia. Economic review 17,1-26 (in Serbian)

Novkov, M., Ristic, Z. 1992. Hunting association of Vojvodina. Hunting association of Vojvodina, Novi Sad, 90 pp. (in Serbian)

Ristic, Z. 2007a. The Importance of Pheasant Population for Hunting Tourism in Vojvodina. Geographica Pannonica 11, 48-53.

Ristic, Z. 1995. Lovoturs since 1955-1995. year. Hunting association of Vojvodina, Novi Sad, 110 pp. (in Serbian)

Ristic, Z. 2005. Lovoturs since 1955-2005. year. Hunting association of Vojvodina, Novi Sad, 133 pp. (in Serbian)

Ristic, Z. 2004. Fowl game as part of hunt-tourism offer of Vojvodina. Hunt newspaper 231, 14-17. (in Serbian)

Ristic, Z. 2007b. Hunting in Vojvodina. Cultural-historic society Pcesa, Novi Sad, 650 pp. (in Serbian)

Todorovic, D.1976. Management of the forest areas. Hunting, forest and agricultural farmland 'Jelen' Belgrade, 78 pp. (in Serbian)

www.vojvodinasume.co.rs 